\title{
ある秩父古生層中の地すべりとその粘土の性状
}

\section{On the clay minerals at the landslide occurred in Chichibu Formation}

\author{
矢嶋澄策* 大山広喜** 鈴木 滋*** \\ Sumisaku Yashima Hiroyoshi Ohyama Shigeru Suzuki
}

\begin{abstract}
After the heavy rain the landslide occurred at the beside of local road near Kuroda village, Manba-cho, Tano -Gun, Gunma Prefecture in Japan on the middle of June, 1974.

By the boring for geological survey and prospect working of this place, we recognized the nature of the test pieces of rocks and clay minerals.

This area mainly consists of schalstein of paleozoic system as we called Chichibu formation including thin layers of slate and chert.

Not only the test boring but also the observations on local tohography, it was considered that many landslides has been occurred from early times.

We can fined the two kinds of clay minerals in the cracks and joints of altered strata. One of them (sample No. 1002 and 1003) has the elements of fine minerals derived from country rocks and also ammounts of clay minerals (micaceous clay minerals and chlorite) and occured from the horizontal thin cracks and joints in the country rocks, not so long continued.

The other (sample No. 1001) comes from the more thick clayey beds of altered zone of schalestein strata, consists of chlorite, micaceous clay and little ammount of montmollironite.

Especially we can recognized the random mixed-layers of mica-montmollironite minerals.

The landslide of this place is considered by such clay minerals as random mixed-layer mica-montmollironite, montmollironite, mica clay minerals and chlorite filling up the pore of rock bed.
\end{abstract}

\section{1. はしがき}

群馬県多野郡万場町黑田地内の県道, 鬼石・ 中里線で 上野村と万場町間の神流川沿いの部分に, 昭和 49 年切取 工竞が始められてから間もなく，7月末から 8 月初にか けて, 数回にわたって集中家雨があった。この大雨の後, 切取りの山腹斜面に大きな偶裂が生じ, 崩壊地すべりの 様相を示し始めた。当時, この亀裂を㣣んで伸縮計を設 置して観測が行なわれたが，8月26日から9月 3 日の間 に最も大きな移動が認められた。8月末になって, 図-1 に示す $\mathrm{A}-\mathrm{A}^{\prime}$ 測線の末端部に表層地すべりが起ったが 9 月以降は，次第にその移動も落ち着きをみせ，遂にはほ ほ安定の状態を保つに至った。その後,この地域で調查 ボーリング, すべり面調查等の調査が行なわれ，地すべ りの機垩について研究され，これに基づき排土工・摧壁 工等の対策工が施工された。

この調査に当って，本地すべりと関連性を持っている と思われる特殊な粘土が認められたので，この粘土の産 状とこの鉙物物性を報告することにしたい。

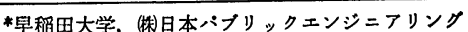

**(穐日本バブリックエンジニフリング

****早稲田大学理学部

\section{2. 位置および地形}

本地域は, 群馬県西部の万場町の西方約 $1 \mathrm{~km}$ の神流 川の右岸にあたる。この川の上流部は, 在来, 地質学的 に著名な山中地溝帯と称されていたところで, 下流の藤 岡町と上流の上野村を結ぶ県道の沿線に当る。この付近 は, 標高 $400 \sim 1,000 \mathrm{~m}$ の壮年期の山地で, 一般に急傾 斜の斜面で河床に接している。また，標高300 $500 \mathrm{~m} の$ 処々には段丘の平坦面が発達している。この平坦面の一 部を占めて黒田と呼ばれる集落が形成されている。この 部落の背後の標高 $700 \mathrm{~m}$ 前後の地域に亀裂の跡があっ て, 過去の地すべりの滑落崖らしい様子を示している。

\section{3. 地質の概要}

この地域の地質は, 古くから多数の研究者によって調 査され，多くの論文が発表されている。すなわち，この 地方の構成地質は, いわゆる秩父古生層に属する輝緑凝 灰岩と, これに付随して粘板岩やチャートによる薄層の 互層と間々石灰岩の小レンズ状層を伴っているものを主 体としている。この地層は，かなり広い分布を示してい るが, 本調査地の黑田部落の付近も全くこの輝緑凝灭岩 を主体とする岩層で構成されている。この岩層は, 全体 として緑褐色細粒のものであるが, 部分的には暗緑色で 
幾分粗粒の磷質部を混えたり，千枚岩状に剥離するやや 厚い砂質部や暗緑色薄層のチャート部を挾在している。
鏡下では, この岩石は, 少量の黒雲母とやや多量の緑泥 石と極く少量の石英 ·斜長石の小晶が認められるが，大 部分は方解石で占められている。部分的で はあるが，石墨が縞状になっているところ があるが，この配列は，外見上の剥離性と 一致している。この岩石中には, 間々円制 上の玄武岩類の岩石が混入している(図-3, 4 参照)。この岩石の一部に厚さ数mmの薄 いものから $1 \mathrm{~cm}$ 以上のやや厚い淡緑また は淡褐色を滞びた粘土の層が挾在されてい る。この層は, ほぼ $\mathrm{N} 40^{\circ} \sim 70^{\circ} \mathrm{W}$ の走向 であるが，北または南に $10^{\circ}$ 前後傾斜して 幾分の乱れの様子を示している。また，こ の岩体にはやや垂直に近い亀裂が多数発達 して括り一見柱状節理のごとき形を示して いる。この垂直龟裂の間隔は数十 $\mathrm{cm}$ から 数的にも及んで，一定の規範があるよらに は思われない。これらの亀裂は, 前述の水 平粘土層に達すると，この粘土層に吸収さ れて，この面より下部には連続していない ことが多い。この垂直の亀裂の上部は，時 にはかなりの幅で空吵を作り，この部分か ら崩落や崩壊が起ったように思われ，水平 の粘土層の面がこの上部の岩塊の水平移動 を助長したよらに思われる。

この地域は, 東西性と南北性の小断層が 多数発達していて, 神流川の流路もこれに 規制されていると思われる。この川の左右 両岸では, 秩父古生層に属する岩石の走向
図-1 群馬県多野郡万場町地すべり地の調查平面図

凡例

調査ボーリソグ個所 同歪計設置個所 裂

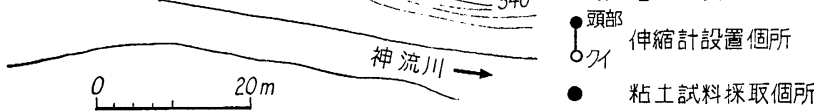

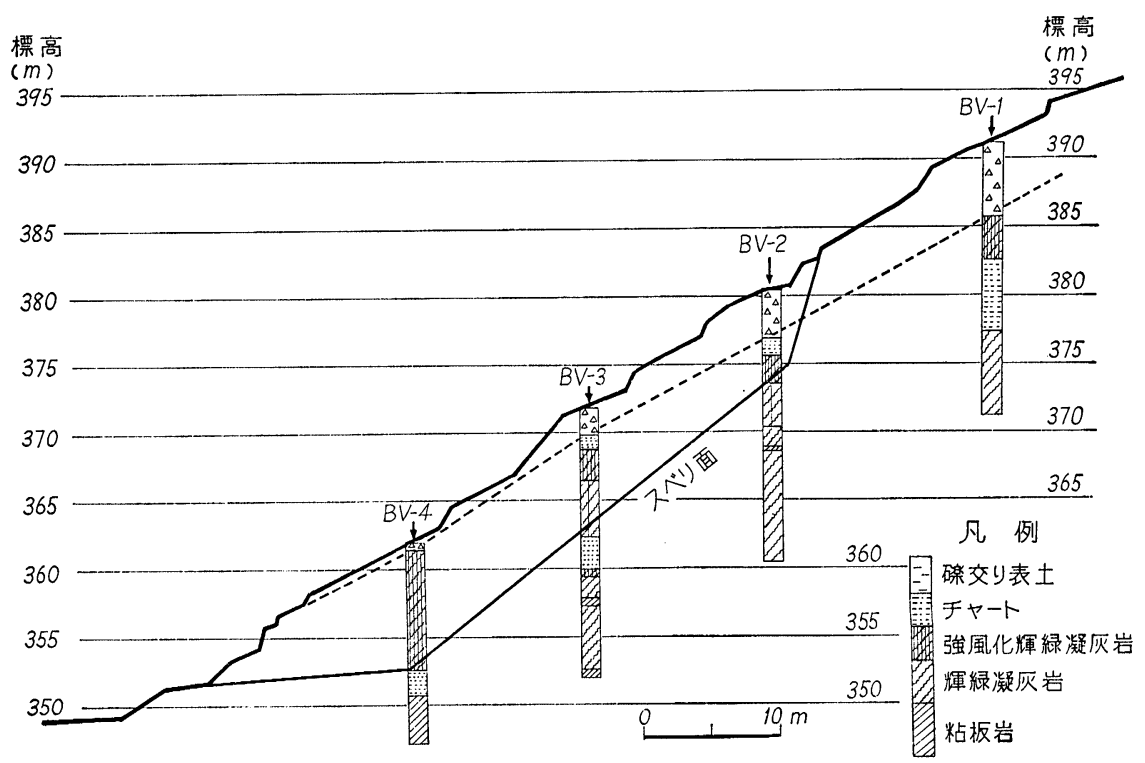

図-2 A-A'測線における断面上の各ボーリング位置とその地質柱状図 
地すべり Vol. 13，No.2（通巻 笛46号）
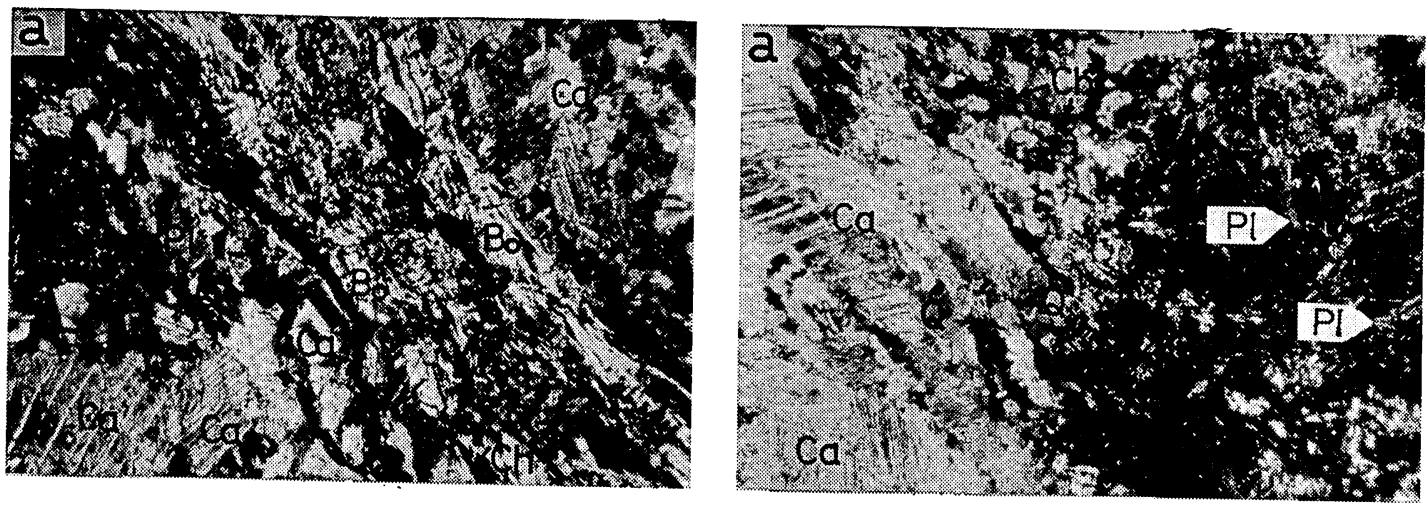

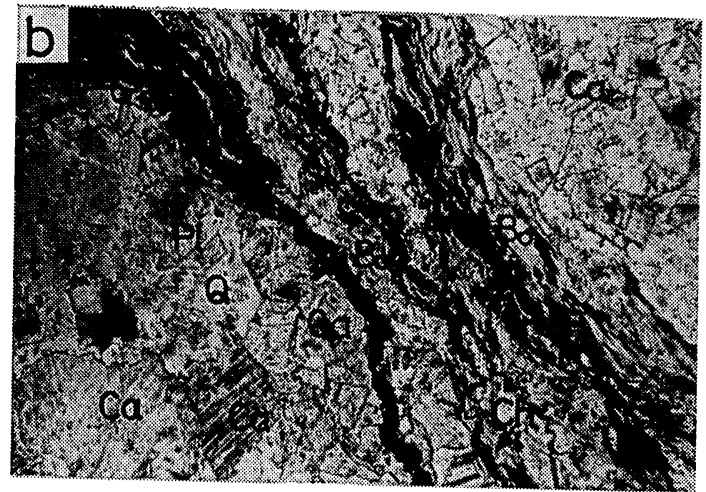

(a)：直交=コル, (b)：平行ニコル

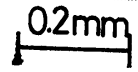

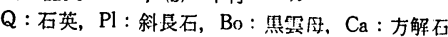

$\mathrm{Ch}:$ 緑泥石, G : 石㟵

图-3 群照県多野郡万場町地すへり地における輝緑凝灭岩 （試料 No. 1005）の薄片の偏光顕微鏡写真

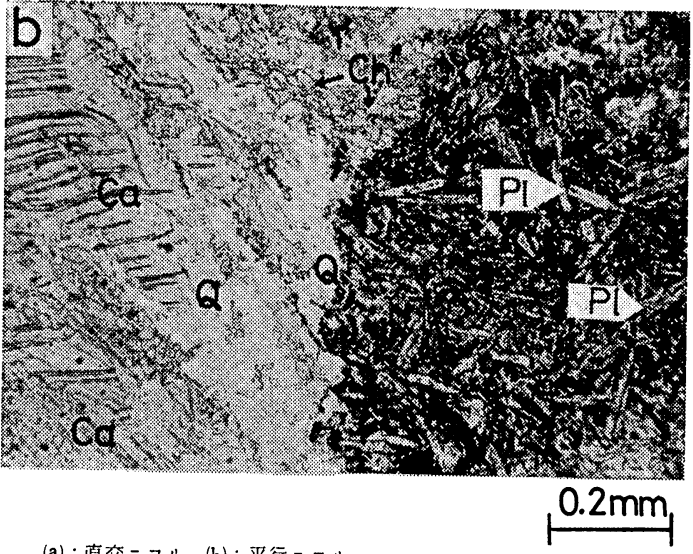

(a)：直交ニコル, (b) : 平行 $=コ ル$

$\mathrm{Q}$ : 石英, $\mathrm{Pl}$ : 斜是石, $\mathrm{Ca}$ : 方解石, $\mathrm{Ch}$ : 緑泥石

図-4 群馬県多野郡万場町地すべり地における偻緑凝扊岩 （試料 No. 1004）の薄片の偏光顕微鏡写真

線からはずれた BV-5 のボーリング孔のコアーを肉眼 鑑定の結果, 輝緑凝灰岩中に互層となって挾在される粘 板岩または珪岩（チャート）の游曆は, 各孔相互の間に 連続性が欠けていることが判明した。これは，以前にこ の地域に発生した地すべりの影響を受けて，この岩層が いくつかの岩塊に分割され, 上下の変動を被った結果か も知れない。特に C-C' $\mathrm{C}^{\prime}$ 测線上の BV-6 と BV-7 の 2 本のボーリングのコアーで認められるように，輝緑凝灰 岩中に挾在している薄層の層準が，2 孔が極めて接近し ている位置にあるにもかかわらずかなり相違している。 このことはあるいは，地層の対比ができないような変位 を受けた疑いを持たしめるのである。

この地域の基盤は, 輝緑凝灰岩を主体にした秩父古生 㬝であるが，この岩層の上部は，全域にわたって著しく 風化して軟弱化している。また，互層を形成している粘 板岩やチャートと輝緑凝灰岩との境界部には厚さ数 $\mathrm{mm}$ から数 $\mathrm{cm}$ の粘土の薄層を挾在していることは, 露出岩 中に認められると同様である。この互層面の粘土幡に沿 って岩塊の移動を起し，地すべりの現象が発生した模様

測線 (図-1, 2参照) 上の BV-1, 2,3,4 の 4 孔と,この測 

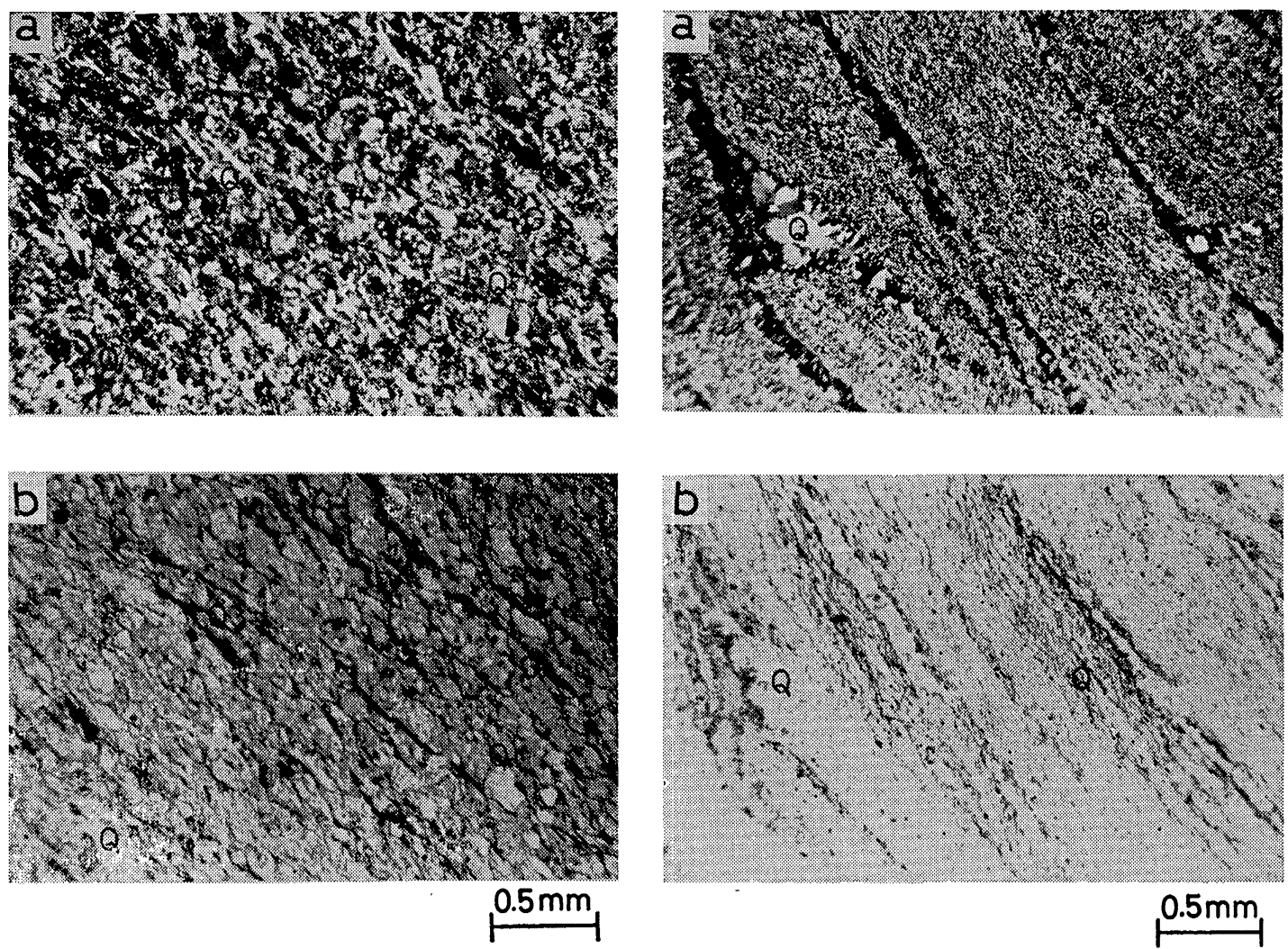

(a) : 直交=コル, (b) : 平行 $=コ ル$

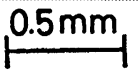

(a)：直交ニコル, (b)：平行 $=コ ル$

$\mathrm{Q}$ : 石英,

図-5 群馬県多野郡万場町地すべり地における粘板岩（試料 No. 1006）の薄片の偏光顕微鏡写真

図-6 群馬県多野郡万場町地すべり地におけるチャート（試 料 No. 1007）の薄片の偏光顕徽鏡写真

表-1 ボーリングによる地下地質調査結果

\begin{tabular}{|c|c|c|c|c|c|c|}
\hline 孔 & ${ }^{\text {樑 }}(\mathrm{m})^{\text {度 }}$ & 㮐 $(\mathrm{m})^{\text {高 }}$ & 表 $\frac{\text { 土厚 }}{(\mathrm{m})}$ & $\begin{array}{c}\text { 風化岩盤樑 } \\
(\mathrm{m})\end{array}$ & 社 $\underset{(\mathrm{m})}{\text { 盤 }}$ 岩 & $\underset{(\mathrm{m})}{\underset{\text { 孔内水位 }}{ }}$ \\
\hline BV-1 & 20.00 & 391.2 & $0 \sim 5.40$ & $5.40 \sim 13.80$ & $13.80 \sim 20.00$ & 13. 50 \\
\hline 2 & 20.00 & 380.4 & $0 \sim 3.50$ & $3.50 \sim 10.00$ & $10.00 \sim 20.00$ & 16. 80 \\
\hline 3 & 20.00 & 370.8 & $0 \sim 2.00$ & 2. $00 \sim 12.50$ & $12.50 \sim 20.00$ & 8.60 \\
\hline 4 & 15. 00 & 362.0 & $0 \sim 0.60$ & $0.60 \sim 11.30$ & $11.30 \sim 15.00$ & 9.00 \\
\hline 5 & 20.00 & 370.0 & $0 \sim 3.90$ & $3.60 \sim 9.20$ & $9.20 \sim 20.00$ & 17. 90 \\
\hline 6 & 20.00 & 380.8 & $0 \sim 1.70$ & $1.70 \sim 12.50$ & $12.50 \sim 20.00$ & 0 \\
\hline 7 & 12.20 & 357.0 & 0 & $0 \sim 9.80$ & $9.80 \sim 12.20$ & 0.70 \\
\hline
\end{tabular}

（注）孔内水位は掘進後ボーリング用水が除去された後の測定值

で，時にこの部分の上下に破础作用が伴った様子が残さ れている。また，上部に分布する強風化の輝緑凝灰岩の 厚い層中に淡褐㕄色の粘土が介在しているが，これは後 に詳述するように，雲母・モンモリロナイト混合層鉱物 (不規則型) である。

古生層の辉緑凝灰岩で構成された地域での地すべり発 生地で，こ種の鈗物が記載された例はいたって僅少で あって，この粘土と地すべり運動との直接因果関係を論 デこことは極めて危険である。しかし，すでに，第三系
頁岩や凝灭岩の分布地域に，ある種の粘土鉱物が発見さ れ，これが地すべりと因果関係のあることが報告（谷津 1965）されているので，この粘土の鉱物学的記载を後述 することとした。

\section{5. 粘土鉱物について}

この地域を構成している岩層には水平またはこれに近 い状態で粘土の薄層が伴ってくることは，すでに述べた と打りである。これは，怙そらく輝緑凝厕岩層中に発達 
していた節理を充埧していたものらしく， それ自体あまり長い連続性を持っていない。 この粘土層にも, 試料 1001 のよ5に層厚 数 $\mathrm{cm}$ の比較的厚層のものと, 試料 1002 , 1003 のよ5に $1 \mathrm{~cm}$ 以下の薄いものなど, 厚䔦雑多であるが, 䔳い,層厚のものは, 帯 緑灰色の粗粒のものが多く, 数 $\mathrm{cm}$ のやや 厚い層厚を示するのは, 帯褐灰色の微粒の 鉱物の集合であることが多い。

これら 3 個の試料についてX線回折法に よる分析を行なった。実験条件は, CuKa 線を使い, 発散(散乱) スリット $1^{\circ}$, 発光 スリット $0.3 \mathrm{~mm}$, 走査速度 $1 \% \mathrm{~min}$, 時 定数 $1 \mathrm{sec}$ である (試料採取の位置は困-1 の平面四に記載した)。これらの試料は, 最 初に水ひと遠心分離によって, 粗い岩桷部 分を除き，そのまま薬液の処理をしない未 処理武料として, 塩酸処理, エチレングリ コール処理および加熱処理 $\left(300^{\circ} \mathrm{C}\right.$ まで) の化学処理を行なってそれぞれX線粉末回 折を行なった。この場合, $2 \mu$ フラクション の微粒試料についてできるだけ粘土鉱物を 定方位とするために，ガラス板に塗布して 測定を行なった。これらの実験から, 図-7. 8,9 のX線回折図形が得られた。

図-7（試料 No. 1001）から，末処理試料 にみられる主なる回折線 $14.5 \AA ， 7.14 \AA$, 4. $73 \AA \AA$, 3. 54Å, 2. $84 \AA$ は, 緑泥石の $(100$ l) に, また, $10.05 \AA, 4.98 \AA, 3.31 \AA$,

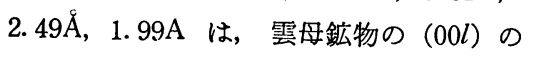
回折線にそれぞれ相当する。14.5A は, 緑 泥石の回折線（001）のものと思われるか， 幾分低角度側にテーリングしているため, エチレングリコール処理を行なったところ， 強度か明らかに減少し, さらにテーリング

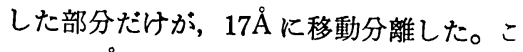
の $14.5 \AA ̊$ の一部が示すこのよらな举動は. モンモリロナイトの特性によく一致する。 すなわち, この試料中にはモンモりロナイ ト*が幾分含まれるものと考えられる。一 方, $10.5 \AA$ の回折線は, この化学処理では

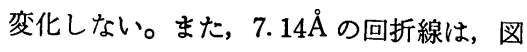
-7に示すように $6 \mathrm{~N} \mathrm{HCl} 1$ 時間の処理で完 全に消隇した。このことから，カオリナイ ト**鈗物は存在しないことになる。末処理

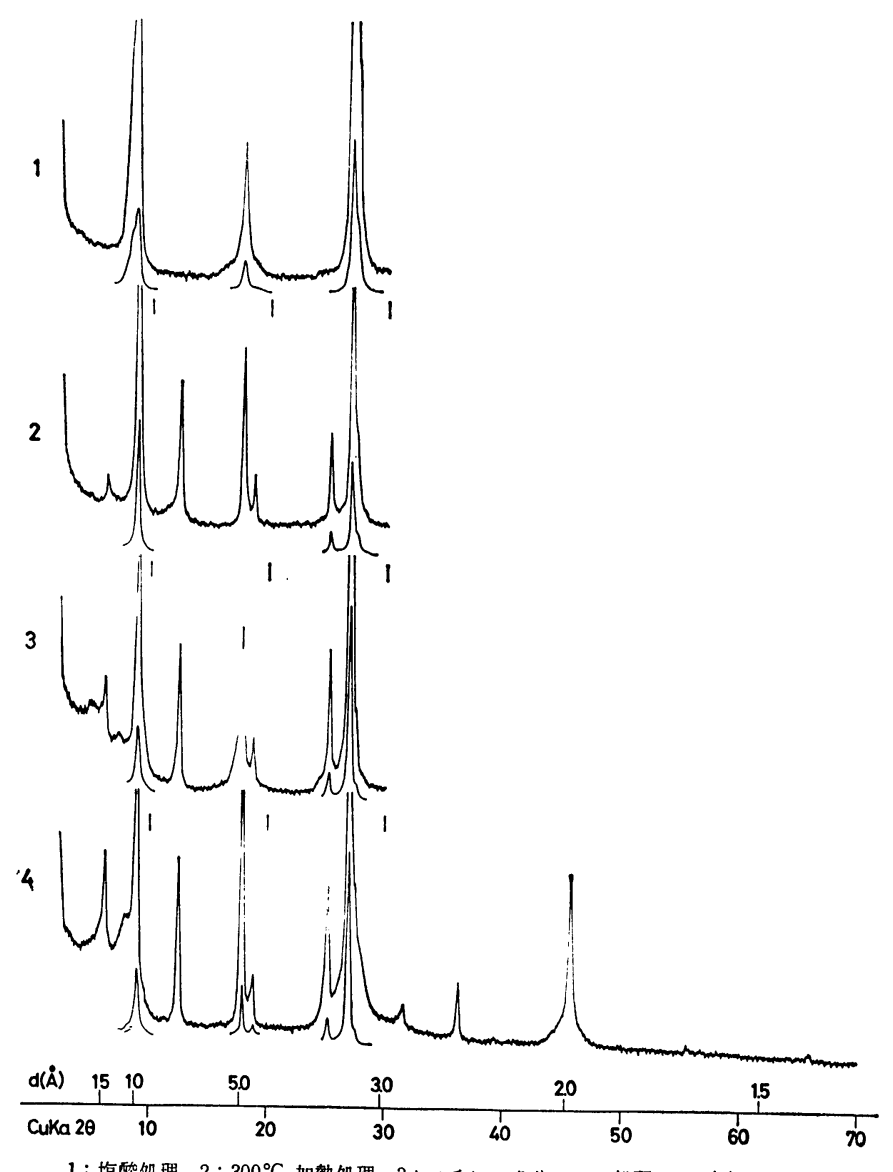

$1:$ 塩酸処理, $2: 300^{\circ} \mathrm{C}$ 加熱処理, $3:$ ×チンクリコール処理, $4:$ 末処理

図-7 未処理と各種処理後の試料 (No. 1001) のX線回折図形

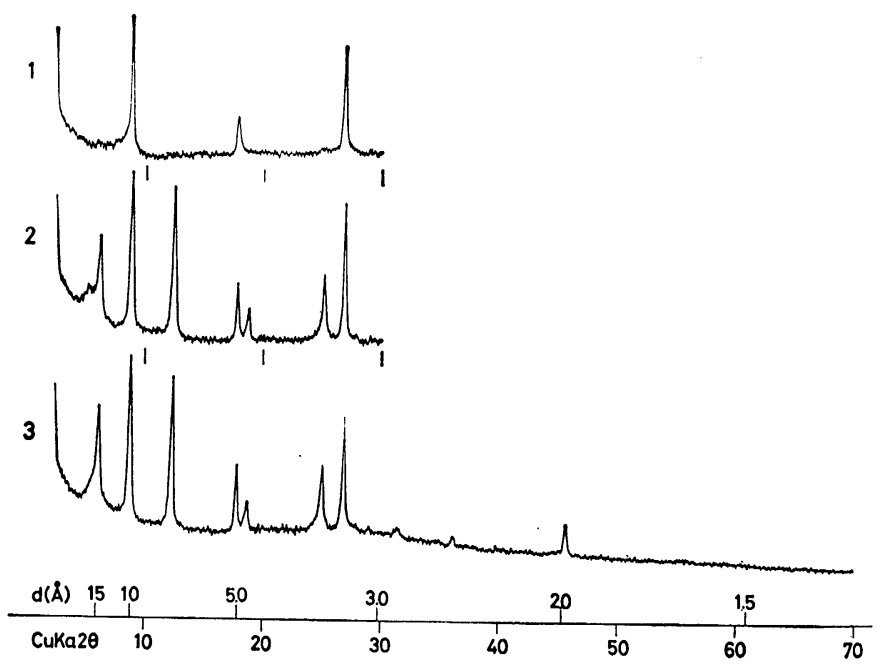

$1:$ 塩酸処理, $2:$ ×レングリコール処理, $3:$ 未処理

図-8 未処理と各種処理の試料 (No. 1002) のX線回折図形

*この報告でもモンモリロナイトと記した鈗物名は、モンモリロナイト鉱物すなわちスメクタイトの意味である。

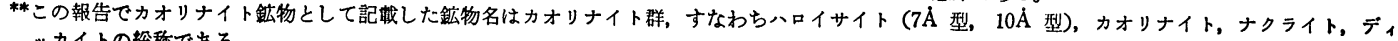
ッカイトの総称である。 


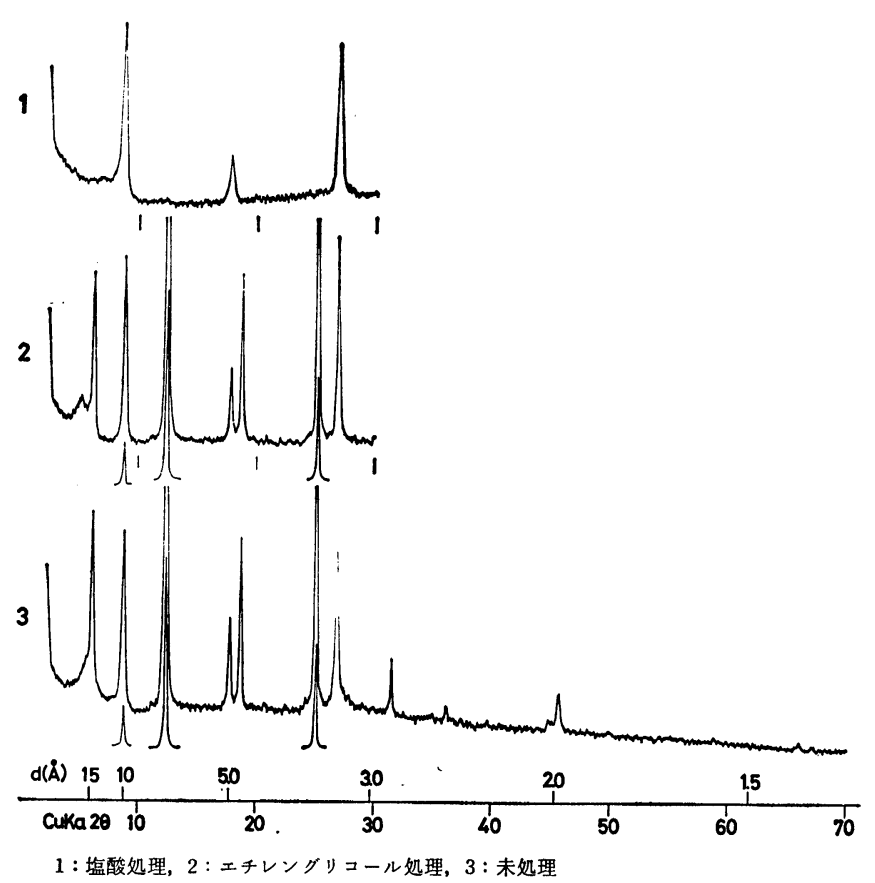

図-9 未処理と各種処理の試料（No. 1003）のX線回折図形
っに地すべりのためたできた割れ目など に,この種の雲母・モンモリロナイト混合 層鉱物が発見されることは，この鉱物と地 すべり現象との間に因果関係があるとの疑 問が持たれるように思われる。

\section{6. あとがき}

群馬県多野郡万場町黒田地内の地すべり について,ボーリング, その他による調查を 行なって地すべりの原因を探究した。その 結果, この地域は, 秩父古生層に属する輝 緑凝灰岩を主体とした岩層で構成され，こ の層間に粘板岩やチャートの薄層を互層と して挾在している。この地域は, 古くから 幾度かの地すべりを起したところで, 処々 に地すべり地形の証查が残されている。地 下の岩層についても, ボーリングっアーの 観察からも, 地層の連続性のらえからも, このことが証明される。さらに，この地す ベりの現象は, 県道施工などの木事業の ためにこの地域の岩層中に保たれていた力 学的平衡状態が破れたらえに, その後烈し

試料の $10.05 \AA ̊$ の雲母粘土鉱物の回折線の肩に及 られ る $11.1 \AA$ の回折線は, エチレングリコール処理で 12. $1 \AA$ に膨潤し, $300^{\circ} \mathrm{C} 1$ 時間の加熱処理で $10 \AA$ に収縮 した。このよらな挙動は, 明瞭な長周期反射が認められ ないことを考慮すると，雲母・モンモリロナイトの不規 則型の混合層を持った鉱物が含まれていることを示して いる。

試料 No. 1002 と No. 1003 とでは, 四-8,9 と示すよ らに，混合層の鉱物は含まれていない。この混合層型の 鉱物を含まないことを除けば，これらの試料は，すへてて 緑泥石, 雲母粘土鉱物拉よびモンモリロナイトによる回 折線が認められる。しかし，その各鉱物の組成は，それ ぞれ異なっていることが認められる。

とくに, この回折線の相対強度から, 雲母鉱物と緑泥 石の含有比率が, No. 1003, No.1002, No. 1001 の順に 大きくなっているよらに思われる。な拉，各試料とも $\mathrm{NH}_{4} \mathrm{NO}_{3}$ および $\mathrm{KCl}+\mathrm{KOH}$ の処理を行なってみたが, バーミキュライト（蛭石）に相当する鉱物が示す顕著な 挙動が認められなかった。

これらの試料について，水ひまたは遠心分離によって， 細粒粘土を分離していない, 粗粒の試料すなわちバルク の試料では母岩中から導入されたと思われる長石, 石英 などの末風化の造岩鉱物の細粒が多量に含まれている。

以上のことから，この地域に発達している秩父古生層 の輝緑凝灰岩体にみられる多くの亀裂または節理の間を 充填した粘土のらち, 特に風化の激しい地域や過去に起

\section{い降雨などの気象条件の变化を受け, 地下水位の急激な} 異変が加わったなどの誘因が重なって, この地域の地層 中に発達した水平粘土層の弱線帯と, この粘土の持つ混 合層鉱物の含水性が助長して崩壞性地すべりを起したも のと思われる。

地すべりについては, 在来多くの研究者によって, 分 類の試みがなされたが, 黒田和男（1960）の提唱した三 つの分類の第一の地表面地すべりとして, 次のように記 されている。すなわち，“風化生成物が地表に近い部分 からしだいに山腹傾斜に応じて低い位置に移動するもの である。このような地すべり地形が形成されるためには， 山腹斜面が著しく急でほとんど風化生成物の静止角に近 いこと, 風化生成物が地すべり現象をるたらす適当な流 動性を帯びた粘土鉱物を作ることが必要である。”また 小出博（1955）は, すでに “その運動の結果, 岩盤は, 粘土化して地すべり粘土ができる。そして，地すべり粘 土の生成は, 地塊の運動をいよい上活発ならしめ……” と述べて, 地すべり現象の背後にはかなり大きく粘土の 滑剂的要素を強調している。しかし, これらの説は, 地 すべり現象の直接の原因か，既存の粘土鉱物の物性に関 係をもっているとは論じていない。本地域の粘土鉣物は, いわゆる在来の断層による粘土と異なり, 地質構成の岩 㬝の節理や空隙を充填していた粘土であって、この粘土 鉱物の物性が地すべり現象発生の直接の誘因となってい るとは速断し難いのであるが，この粘土の構造上の特殊 性が地すべり現象を強化したとも考兄られるのである。 
今後, 地すべり地の地質調査に当っては, 特に粘土鉱 物の存在のあるなし, さらに粘土鉱物が存在している場 合は，その産状について綿密な野外観察やボーリングコ アーの観察を行ない，さらにこの粘土鉱物の物性研究を 行なら必要があるよらに思われる。

本報文をまとめるに当って, 現建設省土木研究所の砂 防部長渡正亮氏には, 調查方法, 調查結果の解析等につ いて葾切な御指尊を頂いた。また，当時の藤岡土木事務 所長田村仁寿郎氏, 同万場承業所長船戸勇氏他関係各位 から紐い御指尊を頂いたことに対し深甚の謝意を捧げた い。また，粘土鉱物のX線同定特よびボーリングコアー の顕微鏡観察については，早稲田大学教育学部の諸子の 労を煩したことに対して万腔の謝意を表する次第であ る。

\section{参考文 献}

1）藤原明做：地すべり機檏解明のための地澌判定について 地すべり Vol.8, No. 2, 1973

2）竹内符雄：地すべりにおける地下調査法について 地すへ $\eta$ Vol. 8, No. 3, 1973

3）黑田和男：地すべりと地質構造の因果関係について 地学 雑誌 Vol. 35, No. 3, 1966

4）黑田和男：地すべりの地犋的分類 地すべりVol. 9 No. 3, 1974
5）竹内篤雄 : 第11回災害科学シンボジウム講演集（山くずれ と地質・地形構造とに関連する研究）士木学会誌 1974

6）田中 茂: 第12回災害科学シンボジウム講演集（地すべり に打ける地下水調查法について）士木学会誌 1975

7）小坂丈序：関東各地の地すべり発生地域における堆程層中 の粘土鉱物の性質と土質特性 土木学会誌 1975

8）谷口敏雄：地すべり対策の問題点 地すべり技術 Vol. 1, No. 2, 1974

9）安藤 武：地すべりの地質的観察 地すべり技術 Vol. 1, No. 5, 1974

10）藤原明敏：平易な地すべり調查法 1 と 2 地すべり技術 Vol. 1, No. 3〜4, 1974

11）湊元光春：地すべり調查における問題点 地すべり技術 Vol. 1, No. 3, 1974

12）藤井宏惊：地すべり地に打けるボーリングの判定について の考え方 地すべり技術 Vol. 2, No. 2， 1975

13）小出 博：日本の地すべりーその予知と対策 日本経済新 報社 1955, 科学 1963

14）藤原明敏：地すべり調查と解析 理工四晢

15）渡 正亮・酒井淳行 : 地すべり地の概查と調查計画の考え 方 地すべり調查と対策講座 VII

16) Keller D. : Soil Clay Mineralogy 1964

17) 谷津栄寿 : 粘土科学 1965

18）金原啓司外 3 : 東北背梁地域に扣ける第三系の变質 西田 彰一教授退官記念諭文集 1976.3

（原稿受理日 昭和51年 3 月 16 日）

\section{原稿料のとりやめについて}

皆様より投稿していただきました原稿にたいし，原 稿料を技払いしてまいりましたが，昭和 50 年 4 月の編 集幹事会で，今後これをとりやめることに決定いたし ました。

その後「地すべり」の「投稿規定」から「揭載原稿 については薄謝を呈します」の項を削除いたしました
が，印刷の手違いで Vol. 12, No.3 と Vol.13, No. 1 で，上項を未削除のまま掲載いたしましたことをこ こに深く沏詫びし，訂正させていただきます。

今後もより立派な学会誌に育て上げるため会員皆様 方の一層の御協力を心から扣願い申し上げをす。

(編集部) 


\begin{tabular}{|c|}
\hline $\begin{array}{l}\text { 最近の茶臼山地すべりの移動特性 } \\
\text { 「地すべり」Vol. 13，No. } 2 \text { (通巻第46号) 1976年（昭和51年）9月 } \\
\text { 望月 巧一 }\end{array}$ \\
\hline 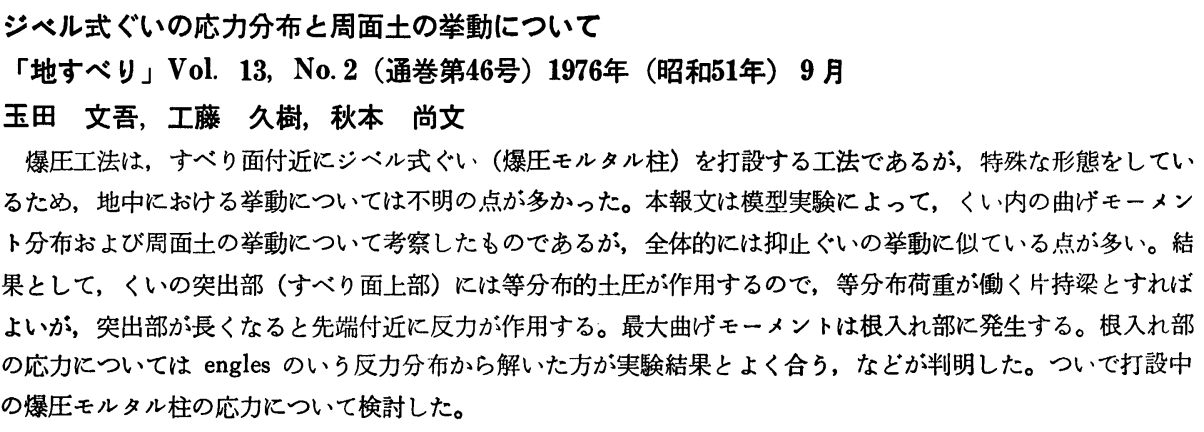 \\
\hline 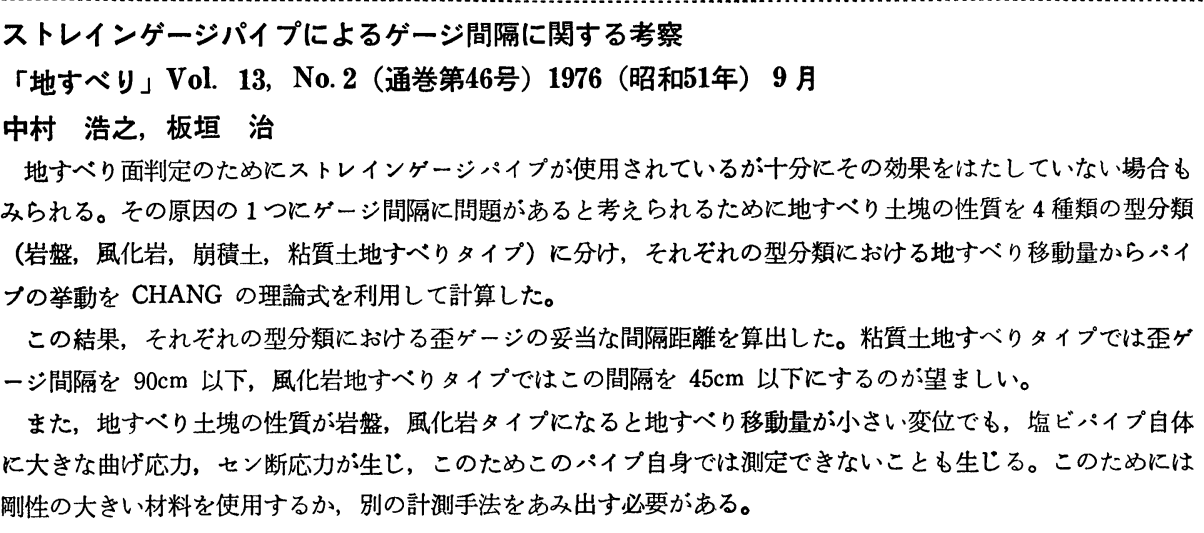 \\
\hline 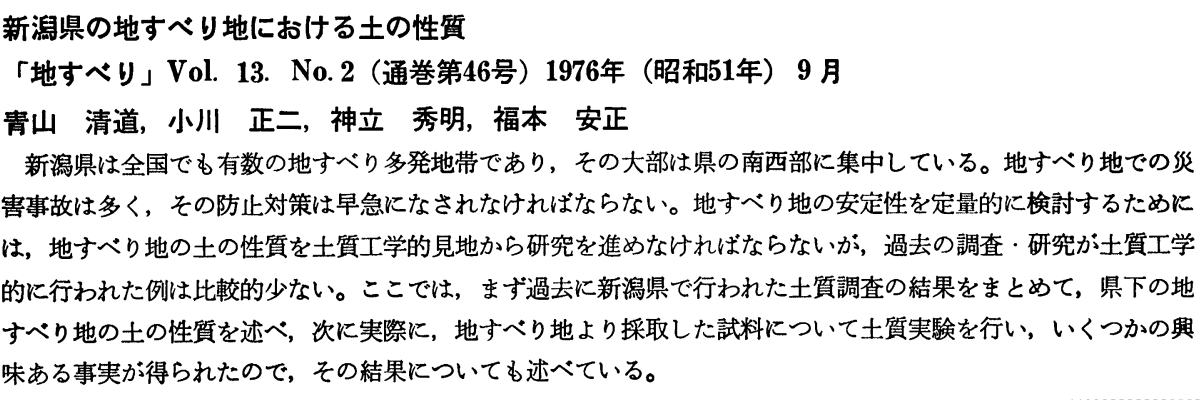 \\
\hline 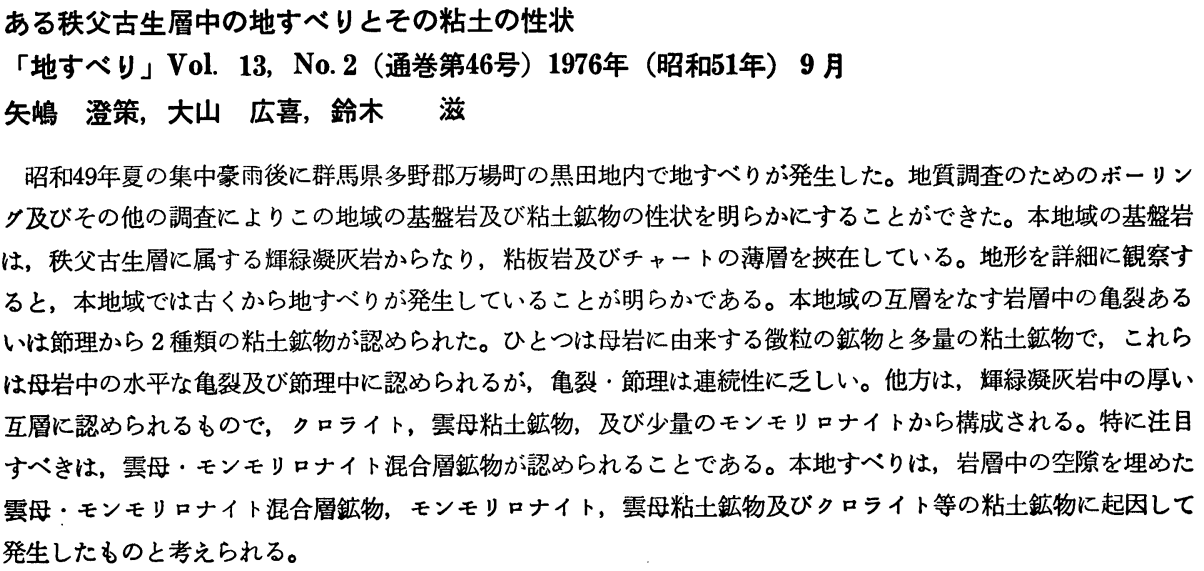 \\
\hline
\end{tabular}

